\title{
A Rapid Technique for Determination of Races of Phytophthora nicotianae on Tobacco
}

\author{
Walter A. Gutiérrez and Asimina L. Mila, Department of Plant Pathology, North Carolina State University, Ra- \\ leigh 27695
}

\begin{abstract}
Gutiérrez, W. A., and Mila, A. L. 2007. A rapid technique for determination of races of Phytophthora nicotianae on tobacco. Plant Dis. 91:985-989.

A laboratory technique for determining races of Phytophthora nicotianae on tobacco (Nicotiana tabacum) was developed and compared with a commonly used greenhouse method. The laboratory technique was based on production and inoculation of tobacco seedlings in tissue culture plates. Three P. nicotianae isolates from North Carolina previously determined as race 0 and 1 were used. Four tobacco cultivars and two breeding lines with different types of resistance were used as differential cultivars: K-326, K-346, NC-71, NC-1071, L8, and Ky14xL8. Plants were evaluated 7 and 14 days after inoculation. Five differential cultivars (K-326, K-346, NC-1071, NC-71, and L8) were determined to be sufficient to differentiate races 0 and 1 . Cv. Ky14xL8 was ineffective for differentiation of races and produced inconsistent results. The laboratory technique was as effective as the greenhouse technique for distinguishing different races of $P$. nicotianae for every isolate in all experiments. Additionally, the most reliable results for both methods were obtained when evaluations were made 14 days after inoculation. The laboratory technique was validated with 21 isolates collected from four counties in North Carolina. The laboratory technique produced results 2 weeks faster than the greenhouse technique and required significantly less space and labor than the greenhouse technique for the same number of isolates. Additionally, the larger number of seedlings used in the laboratory technique increased the robustness of the results, especially for isolates for which race identification was unclear with the greenhouse technique. We propose that the laboratory technique has the potential for evaluation of tobacco resistance in other pathosystems as well.
\end{abstract}

Black shank, caused by Phytophthora nicotianae, is one of the most important diseases of tobacco (Nicotiana tabacum) in the United States and worldwide $(12,15,21)$. The pathogen infects roots, stems, and leaves at any stage of plant growth, resulting in root necrosis, wilting, chlorosis, stem lesions, stunting, and plant death (12). Disease develops rapidly under conditions of high temperature and humidity (12). In North Carolina, annual losses from black shank vary from 1 to $3 \%$, which results in millions of dollars in lost revenue (15).

Black shank is managed by using an integrated approach that includes cultural practices, fungicide applications, and resistant cultivars (18). The most cost-efficient method for managing the disease is the use of resistant cultivars (19). Breeding for resistance started in the early 1900 s and, until the 1960s, the only available source of resistance was derived from 'Fla 301,' a cigar-wrapper tobacco (20). The inheritance of this type of resistance has been

Corresponding author: A. L. Mila

E-mail: almila@ncsu.edu

Accepted for publication 27 February 2007.

doi:10.1094/PDIS-91-8-0985

(C) 2007 The American Phytopathological Society reported to be polygenic (17) and has been incorporated in most commercial cultivars, such as K-326 and K-346. The Fla 301 type of resistance confers partial resistance to all races of $P$. nicotianae that ranges from low to high level (18). Complete resistance to race 0 , the most common race of $P$. nicotianae, is found in $N$. longiflora (phl gene) and N. plumbaginifolia ( $p h p$ gene) $(5,21,22)$. Chaplin (4) chose $N$. plumbaginifolia as the source of black shank resistance for transfer to flue-cured tobacco, whereas Valleau et al. (22) selected $N$. longiflora for transfer of black shank resistance to burley tobacco. It has been shown that resistance to race 0 of $P$. nicotianae from $N$. plumbaginifolia is controlled by a single dominant gene (10). Similar conclusions also have been made for resistance derived from $N$. longiflora (24). Cultivars with this type of resistance are immune to race 0 ; that is, no growth or reproduction of the pathogen occurs in these cultivars. These cultivars carry also some levels of partial resistance from Fla 301.

Isolates of $P$. nicotianae vary widely in aggressiveness $(2,6,20)$. Four races (i.e., 0, 1,2 , and 3 ) of $P$. nicotianae (18) have been described. Races 1 and 0 have been known to be present in the Piedmont and Coastal Plain areas of North Carolina, with race 0 being predominant $(3,12)$. Races 2 and 3 have been reported in South Africa and
Connecticut, respectively $(14,16)$. Recently, race 4 was described from counties in North Carolina and Virginia (9). This race is able to overcome single-gene resistance conferred by the $P h l$ gene from $N$. longiflora but not the Php gene from $N$. plumbaginifolia.

Cultivars with single-gene resistance derived from $N$. longiflora and $N$. plumbaginifolia now fail to provide sufficient control against race 1 of $P$. nicotianae. The existence of race 1 in North Carolina has been known since the 1950s (1). Recently, there has been an increase in the incidence of race 1 associated with the deployment since the mid-1990s of cultivars that have single-gene-mediated resistance to race 0 (18). Sullivan et al. (19) demonstrated that, with continuous deployment of complete resistance, race 1 predominates relative to race 0 within one or two growing seasons The exact distribution of race 1 is unknown, because cultivars with single-genemediated resistance also have different levels of partial resistance from Fla 301 (i.e., provides partial control against all races) that reduces black shank severity and "masks" the exact distribution of race 1.

Thus, there is a need to closely monitor the populations of $P$. nicotianae in fields where complete resistance has been deployed in an effort to preserve the effectiveness of resistant cultivars to manage black shank. Several techniques have been developed for screening breeding lines for resistance to $P$. nicotianae $(13,23-25)$ but not for monitoring the pathogen population. Commonly, races are determined in greenhouse tests by root inoculation of cultivar differentials (18). Csinos (7) evaluated stem versus root inoculation of tobacco cultivars and found a good correlation between stem and percent root infection. Nevertheless, these methods require spacious greenhouse facilities, are labor intensive (because seedlings are transplanted prior to inoculation), and require plants that are 7 to 8 weeks old.

In the 2006 growing season, black shank was a major disease problem primarily in the Piedmont area of North Carolina (A. L. Mila, unpublished) and Virginia (C. Johnson, Department of Plant Pathology, Virginia Tech; personal communication). Numerous producers and consultants requested race determination so that a formal decision could be made about future black shank management (A. L. Mila, unpub- 
lished). For instance, cultivars resistant to race 0 are available; however, if race 1 is present, management options narrow to fungicide applications that are expensive and require timely post-plant applications for best results (7). With the increased interest in race characterization of populations of $P$. nicotianae in commercial tobacco fields, a simple and reliable technique for race characterization was needed.

The objective of this study was to evaluate common breeding lines and commercial cultivars as differential cultivars for race determination and to develop a more efficient, rapid, and low-cost method for identifying different races of $P$. nicotianae.

\section{MATERIALS AND METHODS}

Three isolates of $P$. nicotianae and four tobacco cultivars and two breeding lines were used as differential cultivars. The three $P$. nicotianae isolates were obtained from the collection of Dr. D. H. Shew, North Carolina State University, Department of Plant Pathology: RH2 Rockingham-R1 (characterized as race 1), RM 276 2000-7 K346-49 (characterized as race 0 ), and RM 18-6 (characterized as race 0).

Differential cultivars. Six tobacco cultivars with different types of resistance (differential cultivars) were used: NC-1071 (i.e., flue-cured tobacco breeding line that has the Php resistance gene from N. plumbaginifolia), NC-71 (commercial fluecured tobacco cultivar with similar resistance to NC-1071 plus some unknown level of partial resistance from Fla 301), L8 (burley tobacco breeding line that has the $P h l$ resistance gene from $N$. longifora), Ky14xL8 (commercial burley tobacco cultivar with similar resistance to L8), K326 (commercial flue-cured tobacco cultivar with low level of partial resistance from Fla 301), and K-346 (commercial flue-cured cultivar with high level of partial resistance from Fla 301). The differential cultivars NC-1071, NC-71, L8, and Ky14xL8 have complete resistance to race
0 but are susceptible to race 1 . K-326 and $\mathrm{K}-346$ are susceptible to both race 0 and race $1(4,5,10,14,20,22)$. Both flue-cured and burley lines or cultivars were used because of the different source of complete resistance to race 0 these cultivars carry; that is, the $p h p$ gene in flue-cured tobacco and the $p h l$ gene in burley tobacco. Race 4 has been reported to overcome resistance from the $p h l$ gene but not from the $p h p$ gene (14). Furthermore, both lines and cultivars were examined because seed of tobacco lines is not always easy to obtain and use of cultivars would be a convenient alternative. However, the cultivars carry some levels of partial resistance from Fla 301 that may interfere with the race characterization.

Inoculum preparation. For the laboratory technique, inoculum was prepared by growing the P. nicotianae isolates on $1.7 \%$ cornmeal agar (CMA) with several pieces of sterile Catharanthus roseus (vinca) leaf discs (5 $\mathrm{mm}$ in diameter) placed on the top of the medium as reported by Fichtner et al. (8). Dishes were incubated at room temperature $\left(20\right.$ to $25^{\circ} \mathrm{C}$ ) in the dark for 7 to 10 days until all vinca leaf discs were fully colonized by fungal mycelium. For the greenhouse technique, inoculum was prepared by placing rice grains, sterilized at $121^{\circ} \mathrm{C}$ for $30 \mathrm{~min}$ for 3 consecutive days, on a 3-day-old CMA agar culture of each $P$. nicotianae isolate. Subsequently, the rice grains were incubated for 7 to 9 days at room temperature $\left(20\right.$ to $25^{\circ} \mathrm{C}$ ) before inoculation.

Technique description. Laboratory. Tobacco cultivars were grown in 12-cell tissue culture (TC) plates (Corning Incorporated, Corning, NY). Each cell was filled with $3.5 \mathrm{~cm}^{3}$ of perlite $(<2 \mathrm{~mm}$ in size) and $1.5 \mathrm{ml}$ of deionized water. In all, 10 to 16 seeds were placed in each cell (one cultivar per cell; Fig. 1). Cultivars were not randomized within the plates (Fig. 1A). Cultivars were planted in a pattern so that a flue-cured tobacco cultivar with single-gene resistance to race 0 was next to a cultivar with no single-gene resistance or a burley tobacco cultivar with single-gene resistance. Water was added in the space between cells to provide additional moisture. Seeded plates then were incubated under $12 \mathrm{~h}$ of dark and light (two 45-W cool florescent lights placed at $55 \mathrm{~cm}$ above TC plates) at room temperature $\left(20\right.$ to $\left.25^{\circ} \mathrm{C}\right)$. A $0.5-\mathrm{ml}$ solution of $\mathrm{N}$ fertilizer at $200 \mathrm{ppm}$ (Bulldog watersoluble fertilizer 20-10-20; Chilean Nitrate Corporation, Northfolk, VA) per cell was added 10 days after seeding and once every week thereafter. The water level in cells of TC plates was checked twice a week to control an excess of water that could form in the central cell of the plate due to condensation. Seedlings (25 days old) were inoculated by placing one piece of colonized vinca (C. roseus) leaf disc ( 5 $\mathrm{mm}$ in diameter) per cell on the surface of the growing medium. After inoculation, five to six TC plates were placed into a 40by-27-by-8-cm plastic container (Max Klein Co., Baraboo WI) and covered with a 55-by-46-cm polyvinyl-chloride laboratory wrap (Fisher Scientific Company, Pittsburgh) to create a moist chamber. The containers then were incubated in a growth chamber at $27.5^{\circ} \mathrm{C}$ with $13 \mathrm{~h}$ of light and $23^{\circ} \mathrm{C}$ with $11 \mathrm{~h}$ of dark. Each cultivar was seeded in two cells of each TC plate, one isolate of the pathogen was used per plate, and three to four plates were used per isolate. The laboratory technique was repeated once.

Greenhouse. The protocol for the greenhouse technique was described in detail by Sullivan et al. (18). Briefly, seed of each cultivar mentioned above were seeded into 20 -cm pots with potting mix (Metromix 220; The Scotts Company, Marysville, $\mathrm{OH})$ and allowed to grow for 3 weeks. After 3 weeks, the plants were transplanted into cell packs ( 72 cells, 4 by 4 by $5 \mathrm{~cm}$ ) containing a 1:1:1 (vol/vol/vol) mixture of steam-pasteurized soil, Metromix, and
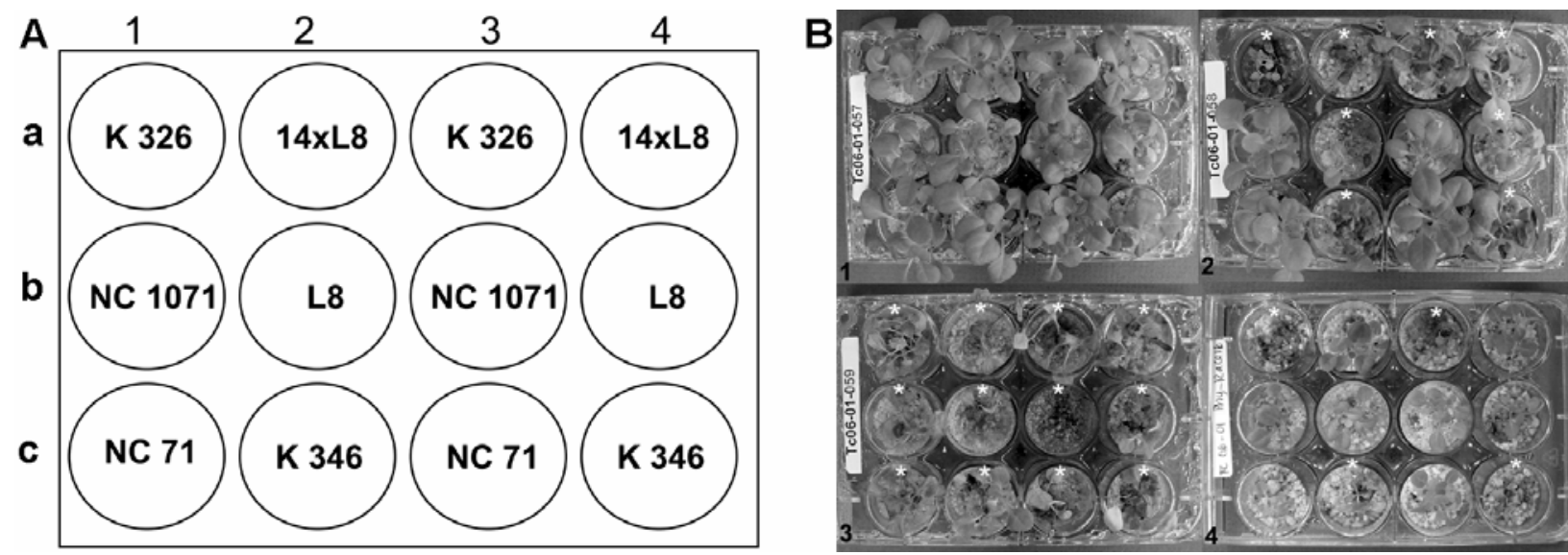

Fig. 1. A, Arrangement of the six differential cultivars in a tissue culture plate. Each cell was filled with $3.5 \mathrm{~cm}^{3}$ of perlite $(<2 \mathrm{~mm}$ in size $)$ and $1.5 \mathrm{ml}$ of deionized water. B, 1, noninoculated tissue culture plate with plants healthy in every cell; 2, tissue culture plate inoculated with isolate RM 27-6 2000-7 $\mathrm{K} 346-49$; 3, tissue culture plate inoculated with isolate Rockingham-R1; and 4, tissue culture plate inoculated with isolate RM 18-6; * indicates cells with infected or dead plants. 
coarse builder's sand. All plants were watered daily, fertilized as needed with Peter's 20-20-20 water-soluble fertilizer (Spectrun Group, Division of United Industries Corp., St. Louis), and allowed to grow an additional 7 to 10 days before inoculation. Inoculation was performed by placing two rice grains colonized by $P$. nicotianae inside the potting mix in each cell. After inoculation, the plants were watered. The greenhouse technique was repeated once. Each greenhouse experiment consisted of three plants per cultivar per isolate, replicated three times in a randomized complete block design.

Disease assessment, data collection, and statistical analysis. In the laboratory, germination was evaluated 2 weeks after seeding to obtain the total number of plants per cell before inoculation. Disease incidence was evaluated 7 and 14 days after inoculation for both the laboratory and greenhouse technique. Plants with chlorosis, wilting, dark root system and general symptoms of necrosis, and death were assessed as infected by $P$. nicotianae (12). Percentage of infected plants was defined as disease incidence. Disease incidence data $x$ were log-transformed to $i=$ $\log _{10}(x+1)$ and then analyzed. Analysis of variance (ANOVA) was conducted using the generalized linear models in SAS (SAS Institute, Cary, NC) for the mean disease incidence for each inoculation technique 7 and 14 days after inoculation. Significant differences among means were determined by Fisher's least significant difference at $P$ $=0.05$. Generally, a line or cultivar was considered susceptible if more than $5 \%$ of the plants were infected and if the results were consistent among repetitions (plates).

Evaluation of laboratory technique. Twenty-one isolates of $P$. nicotianae collected from four counties of North Carolina in September 2005 were used to validate the laboratory technique. All sampled fields were planted with tobacco and experienced severe losses from black shank in 2004. Nine isolates were obtained from a soil sample from a field in Edgecombe
County (denoted as Edge), six from a soil sample from a field in Hoke County (denoted as Hoke), four from a soil sample from a field in Yadkin County (denoted as Yad), and two from a soil sample from a field in Person County (denoted as P). The experiment was performed as described above and was conducted two times for each isolate.

\section{RESULTS}

The laboratory technique was as effective as the greenhouse technique for distinguishing races of $P$. nicotianae for all isolates evaluated except isolate Rockingham-R1 at the 7-day evaluation following inoculation for experiment 1 . In this experiment at the 7-day evaluation, a higher percentage of plants with black shank symptoms was found with the laboratory technique than the greenhouse technique. Nevertheless, 14 days after inoculation, both the greenhouse and the laboratory techniques yielded similar results for all isolates evaluated (Table 1). The laboratory technique provided consistent results as early as 7 days after inoculation; this was not always the case for the greenhouse technique (Table 1). Nevertheless, the most reliable results for both methods were with the evaluation at 14 days after inoculation (Fig. 1B; Table 1).

The differential cultivars NC-1071 and NC-71, with complete resistance to race 1 , and K-326, with low partial resistance to both races, distinguished race 1 from race 0 even with the first evaluation 7 days after inoculation (Fig. 1B; Table 1). K-346, with high partial resistance to races 0 and 1 , had the same reaction as K-326 except with the isolate RM 18-6 at the 7-day evaluation. L8 and Ky14xL8 were speculated to have similar responses to $\mathrm{NC}-1071$ and NC-71 following inoculation. However, moderate levels of mortality were found on L8 and $14 x$ L8 following inoculation with isolate RM 27-6 2000-7 K346-49 using both the laboratory and the greenhouse techniques (Table 1). Although this isolate originally was characterized as race 0 , both tech- niques indicated that it actually could belong to a different race.

Ky14xL8 had moderate levels of mortality with isolate RM 18-6 in the laboratory but not in the greenhouse. In all, 42 seedlings of Ky14xL8 in the laboratory versus 18 plants in the greenhouse were inoculated with RM 18-6. A larger number of plants may increase the probability of getting a low rate of infection.

Twenty-one isolates were used to validate the laboratory technique. Three isolates (i.e., Edge A-1, Edge A-31, and Edge A-33) exhibited typical race 0 behavior (that is, only plants from K-326 and K-346 showed black shank symptoms). Five additional isolates were classified as race 0; however, with these isolates, Ky14xL8 but not L8 had low levels of mortality as well (Table 2). Thirteen isolates were identified as race 1; at the 14-day evaluation, all differential cultivars exhibited some level of mortality different than 0 . This level of mortality fluctuated significantly among isolates. For some isolates, like Hoke A-3, it was $100 \%$ for all cultivars or lines (Table 2). But for some others, like Edge A-16, it ranged from $100 \%$ for $\mathrm{K}-326$ and $\mathrm{K}-346$ to as low as $5 \%$ for NC-71. This percentage was very low; however, the differential cultivar was considered to be susceptible because mortality was observed in all repetitions (plates) of this cultivar with this isolate.

\section{DISCUSSION}

Four commercial tobacco cultivars and two breeding lines were investigated for their ability to discriminate among different races of $P$. nicotianae. Csinos (7) characterized the race of $42 P$. nicotianae isolates by inoculating in the greenhouse three plants of the commercial tobacco cv. K-326 (without the $P h$ gene that confers complete resistance to race 0 ) and the breeding line NC-1071 (with the $P h$ gene that confers complete resistance to race 0 ). In other studies $(18,19)$, four differential cultivars have been used: Hicks, K-326, NC-1071, and Ky14xL8. McIntyre $(13,14)$

Table 1. Percentage of tobacco plants with symptoms of black shank 7 and 14 days after inoculation of tobacco cultivars and lines with three isolates of Phytophthora nicotianae ${ }^{\mathrm{w}}$

\begin{tabular}{|c|c|c|c|c|c|c|c|c|c|c|c|c|c|c|}
\hline \multirow[b]{3}{*}{$\mathrm{Cv}^{\mathrm{z}}$} & & & \multicolumn{6}{|c|}{7 days after inoculation ${ }^{x}$} & \multicolumn{6}{|c|}{14 days after inoculation ${ }^{x}$} \\
\hline & \multicolumn{2}{|c|}{ Reaction $^{\mathrm{y}}$} & \multicolumn{3}{|c|}{ Laboratory technique } & \multicolumn{3}{|c|}{ Greenhouse technique } & \multicolumn{3}{|c|}{ Laboratory technique } & \multicolumn{3}{|c|}{ Greenhouse technique } \\
\hline & $\mathbf{0}$ & 1 & Rock & RM27 & RM18 & Rock & RM27 & RM18 & Rock & RM27 & RM18 & Rock & RM27 & RM18 \\
\hline NC-1071 & $\mathrm{R}$ & $\mathrm{S}$ & $82.2 \mathrm{ab}$ & $6.3 \mathrm{~b}$ & $0.0 \mathrm{c}$ & $73.3 \mathrm{a}$ & $0.0 \mathrm{~b}$ & $0.0 \mathrm{~b}$ & $96.4 \mathrm{ab}$ & $6.3 \mathrm{c}$ & $0.0 \mathrm{c}$ & $100 \mathrm{a}$ & $16.7 \mathrm{bc}$ & $0.0 \mathrm{~b}$ \\
\hline NC-71 & $\mathrm{R}$ & $\mathrm{S}$ & $70.5 \mathrm{~b}$ & $0.0 \mathrm{~b}$ & $0.0 \mathrm{c}$ & $27.8 \mathrm{~b}$ & $0.0 \mathrm{~b}$ & $0.0 \mathrm{~b}$ & $91.3 \mathrm{~b}$ & $4.4 \mathrm{c}$ & $0.0 \mathrm{c}$ & $94.5 \mathrm{a}$ & $0 \mathrm{c}$ & $0.0 \mathrm{~b}$ \\
\hline L8 & $\mathrm{R}$ & $\mathrm{S}$ & $72.7 \mathrm{ab}$ & $20.5 \mathrm{~b}$ & $0.0 \mathrm{c}$ & $100 \mathrm{a}$ & $16.7 \mathrm{~b}$ & $0.0 \mathrm{~b}$ & $97.1 \mathrm{ab}$ & $43.1 \mathrm{~b}$ & $1.3 \mathrm{c}$ & $100 \mathrm{a}$ & $55.6 \mathrm{ab}$ & $0.0 \mathrm{~b}$ \\
\hline Ky14xL8 & $\mathrm{R}$ & $\mathrm{S}$ & $93.3 \mathrm{a}$ & $18.8 \mathrm{~b}$ & $36.2 \mathrm{~b}$ & $83.4 \mathrm{a}$ & $16.7 \mathrm{~b}$ & $0.0 \mathrm{~b}$ & $100 \mathrm{a}$ & $63.7 \mathrm{~b}$ & $39.1 \mathrm{~b}$ & $94.5 \mathrm{a}$ & $72.2 \mathrm{a}$ & $0.0 \mathrm{~b}$ \\
\hline K-326 & $\mathrm{S}$ & $\mathrm{S}$ & $84.3 \mathrm{ab}$ & $73.3 \mathrm{a}$ & $77.9 \mathrm{a}$ & $33.3 \mathrm{~b}$ & $44.5 \mathrm{a}$ & $22.2 \mathrm{a}$ & $100 \mathrm{a}$ & $95.6 \mathrm{a}$ & $98.2 \mathrm{a}$ & $94.5 \mathrm{a}$ & $88.9 \mathrm{a}$ & $77.8 \mathrm{a}$ \\
\hline $\mathrm{K}-346$ & $S$ & $S$ & $74.4 \mathrm{ab}$ & $70.1 \mathrm{a}$ & $13.8 \mathrm{c}$ & $33.3 \mathrm{~b}$ & $40.4 \mathrm{a}$ & $22.2 \mathrm{a}$ & $98.8 \mathrm{ab}$ & $98.8 \mathrm{a}$ & $96.3 \mathrm{a}$ & $100 \mathrm{a}$ & $86.7 \mathrm{a}$ & $77.8 \mathrm{a}$ \\
\hline
\end{tabular}

${ }^{\mathrm{w}}$ For the laboratory technique, inoculum consisted of Catharanthus roseus leaf discs fully colonized by mycelium of each Phytophthora nicotianae isolate. For the greenhouse technique, inoculum was rice grains colonized by mycelium of each $P$. nicotianae isolate. The experiment was repeated once. Percentage of infected plants per cultivar or line is presented. Numbers are means of two experiments. Means within columns with the same letter do not differ significantly with the least significant difference procedure at $P=0.05$.

x Abbreviations: Rock = Rockingham-R1, RM27 = RM 27-6 2000-7 K346-49, RM18 = RM 18-6.

${ }^{\mathrm{y}}$ Expected reaction to race 0 or $1 ; \mathrm{R}=$ resistant and $\mathrm{S}=$ susceptible.

${ }^{\text {z }}$ Differential cultivar. 
used the breeding lines NC-1071 and L8 to identify race 3 of $P$. nicotianae in Connecticut. In that case, plants of L8 demonstrated black shank symptoms but not NC-
1071 (14). Hence, a reevaluation of the differential cultivars used to determine races of $P$. nicotianae was considered necessary.

Table 2. Race determination of 21 isolates of Phytophthora nicotianae using the laboratory technique and six differential cultivars ${ }^{y}$

\begin{tabular}{|c|c|c|c|c|c|c|c|}
\hline Isolate & $\begin{array}{c}\text { Differential } \\
\text { cultivar }\end{array}$ & 14 days $^{z}$ & Race & Isolate & $\begin{array}{l}\text { Differential } \\
\text { cultivar }\end{array}$ & 14 days $^{z}$ & Race \\
\hline \multirow[t]{6}{*}{ Edge A-26 } & K326 & $100 \mathrm{a}$ & \multirow[t]{6}{*}{0} & \multirow{6}{*}{ Hoke A-4 } & L8 & $100.0 \mathrm{a}$ & \\
\hline & $14 x L 8$ & $31.3 \mathrm{~b}$ & & & NC71 & $100.0 \mathrm{a}$ & \\
\hline & 1071 & $0.0 \mathrm{c}$ & & & K346 & $100.0 \mathrm{a}$ & \\
\hline & L8 & $0.0 \mathrm{c}$ & & & K326 & $93.8 \mathrm{a}$ & 1 \\
\hline & NC71 & $0.0 \mathrm{c}$ & & & $14 x L 8$ & $100.0 \mathrm{a}$ & \\
\hline & K346 & $95.0 \mathrm{a}$ & & & 1071 & $78.0 \mathrm{a}$ & \\
\hline \multirow[t]{6}{*}{ Edge A-31 } & K326 & $95.0 \mathrm{a}$ & \multirow[t]{6}{*}{0} & & L8 & $79.2 \mathrm{a}$ & \\
\hline & $14 x L 8$ & $0.0 \mathrm{~b}$ & & & NC71 & $83.4 \mathrm{a}$ & \\
\hline & 1071 & $0.0 \mathrm{~b}$ & & & K346 & $78.4 \mathrm{a}$ & \\
\hline & L8 & $0.0 \mathrm{~b}$ & & Hoke A-23 & K326 & $100.0 \mathrm{a}$ & 1 \\
\hline & NC71 & $0.0 \mathrm{~b}$ & & & $14 x L 8$ & $75.0 \mathrm{ab}$ & \\
\hline & K346 & $95.0 \mathrm{a}$ & & & 1071 & $43.7 \mathrm{bc}$ & \\
\hline \multirow[t]{6}{*}{ Edge A-1 } & K326 & $83.8 \mathrm{a}$ & \multirow[t]{6}{*}{0} & & L8 & $41.0 \mathrm{bc}$ & \\
\hline & $14 \times$ L8 & $0.0 \mathrm{~b}$ & & & NC71 & $0.0 \mathrm{c}$ & \\
\hline & 1071 & $0.0 \mathrm{~b}$ & & & K346 & $55.0 \mathrm{ab}$ & \\
\hline & L8 & $0.0 \mathrm{~b}$ & & Yad A-36 & K326 & $95.0 \mathrm{a}$ & 1 \\
\hline & NC71 & $0.0 \mathrm{~b}$ & & & $14 x L 8$ & $94.5 \mathrm{a}$ & \\
\hline & K346 & $72.8 \mathrm{a}$ & & & 1071 & $32.2 \mathrm{c}$ & \\
\hline \multirow[t]{6}{*}{ Edge A-10 } & K326 & $85.0 \mathrm{a}$ & \multirow[t]{6}{*}{0} & & L8 & $51.9 \mathrm{bc}$ & \\
\hline & 14xL8 & $5.0 \mathrm{~b}$ & & & NC71 & $80.0 \mathrm{ab}$ & \\
\hline & 1071 & $0.0 \mathrm{~b}$ & & & K346 & $57.2 \mathrm{bc}$ & \\
\hline & L8 & $0.0 \mathrm{~b}$ & & P46B-L1 & K326 & $75 \mathrm{a}$ & 1 \\
\hline & NC71 & $0.0 \mathrm{~b}$ & & & $14 \times$ L8 & $100 \mathrm{a}$ & \\
\hline & K346 & $50.0 \mathrm{ab}$ & & & 1071 & $55.0 \mathrm{a}$ & \\
\hline \multirow[t]{6}{*}{ Edge A-13 } & K326 & $83.4 \mathrm{a}$ & \multirow[t]{6}{*}{0} & & L8 & $57.2 \mathrm{a}$ & \\
\hline & $14 x L 8$ & $13.7 \mathrm{~b}$ & & & NC71 & $55 \mathrm{a}$ & \\
\hline & 1071 & $0.0 \mathrm{~b}$ & & & K346 & $75.5 \mathrm{a}$ & \\
\hline & L8 & $0.0 \mathrm{~b}$ & & P52A-L1 & K326 & $15.1 \mathrm{c}$ & 1 \\
\hline & NC71 & $0.0 \mathrm{~b}$ & & & $14 \times$ L8 & $90.7 \mathrm{a}$ & \\
\hline & K346 & $51.1 \mathrm{ab}$ & & & 1071 & $65.7 \mathrm{~b}$ & \\
\hline \multirow[t]{6}{*}{ Edge A-12 } & K326 & $67.5 \mathrm{a}$ & \multirow[t]{6}{*}{0} & & L8 & $60.0 \mathrm{~b}$ & \\
\hline & $14 x L 8$ & $5.6 \mathrm{~b}$ & & & NC71 & $24.5 \mathrm{c}$ & \\
\hline & 1071 & $0.0 \mathrm{~b}$ & & & K346 & $17.3 \mathrm{c}$ & \\
\hline & L8 & $0.0 \mathrm{~b}$ & & Yad A-31 & K326 & $87.5 \mathrm{a}$ & 1 \\
\hline & NC71 & $0.0 \mathrm{~b}$ & & & $14 x L 8$ & $80.0 \mathrm{a}$ & \\
\hline & K346 & $70.0 \mathrm{a}$ & & & 1071 & $50.0 \mathrm{a}$ & \\
\hline Edge A-33 & K326 & $95.0 \mathrm{a}$ & 0 & & L8 & $81.3 \mathrm{a}$ & \\
\hline & $14 x L 8$ & $0.0 \mathrm{c}$ & & & NC71 & $100.0 \mathrm{a}$ & \\
\hline & 1071 & $0.0 \mathrm{c}$ & & & K346 & $79.5 \mathrm{a}$ & \\
\hline & L8 & $0.0 \mathrm{c}$ & & Yad A-46 & K326 & $55.6 \mathrm{a}$ & 1 \\
\hline & NC71 & $0.0 \mathrm{c}$ & & & $14 x L 8$ & $44.5 \mathrm{a}$ & \\
\hline & K346 & $75.0 \mathrm{~b}$ & & & 1071 & $5.6 \mathrm{a}$ & \\
\hline Edge A-7 & K326 & $33.3 \mathrm{a}$ & 0 & & L8 & $17.1 \mathrm{a}$ & \\
\hline & 14 x L8 & $5 \mathrm{~b}$ & & & NC71 & $21.1 \mathrm{a}$ & \\
\hline & 1071 & $0 \mathrm{~b}$ & & & K346 & $15.6 \mathrm{a}$ & \\
\hline & L8 & $0 \mathrm{~b}$ & & Hoke A-9 & K326 & $94.5 \mathrm{a}$ & 1 \\
\hline & NC71 & $0 \mathrm{~b}$ & & & $14 x L 8$ & $100.0 \mathrm{a}$ & \\
\hline & K346 & $75 \mathrm{a}$ & & & 1071 & $55.0 \mathrm{a}$ & \\
\hline Edge A-16 & K326 & $100.0 \mathrm{a}$ & 1 & & L8 & $71.4 \mathrm{a}$ & \\
\hline & $14 x L 8$ & $72.3 \mathrm{a}$ & & & NC71 & $100.0 \mathrm{a}$ & \\
\hline & 1071 & $8.4 \mathrm{~b}$ & & & K346 & $100.0 \mathrm{a}$ & \\
\hline & L8 & $16.9 \mathrm{~b}$ & & Hoke A-5 & K326 & $100.0 \mathrm{a}$ & 1 \\
\hline & NC71 & $5 \mathrm{~b}$ & & & $14 x L 8$ & $100.0 \mathrm{a}$ & \\
\hline & K346 & $100.0 \mathrm{a}$ & & & 1071 & $62.5 \mathrm{ab}$ & \\
\hline Hoke A-12 & K326 & $100.0 \mathrm{a}$ & 1 & & L8 & $60.4 \mathrm{~b}$ & \\
\hline & 14xL8 & $100.0 \mathrm{a}$ & & & NC71 & $100.0 \mathrm{a}$ & \\
\hline & 1071 & $86.4 \mathrm{a}$ & & & K346 & $100.0 \mathrm{a}$ & \\
\hline & L8 & $80.7 \mathrm{a}$ & & Yad A-8 & K326 & $44.4 \mathrm{ab}$ & 1 \\
\hline & NC71 & $94.5 \mathrm{a}$ & & & $14 x L 8$ & $75.0 \mathrm{a}$ & \\
\hline & K346 & $70.0 \mathrm{a}$ & & & 1071 & $35.4 \mathrm{ab}$ & \\
\hline Hoke A-3 & K326 & $100.0 \mathrm{a}$ & 1 & & L8 & $4.6 \mathrm{~b}$ & \\
\hline & 14xL8 & $100.0 \mathrm{a}$ & & & NC71 & $25.0 \mathrm{ab}$ & \\
\hline & 1071 & $100.0 \mathrm{a}$ & & & K346 & $37.8 \mathrm{ab}$ & \\
\hline
\end{tabular}

y Inoculum was Catharanthus roseus leaf discs were fully colonized by fungal mycelium of each $P$. nicotianae isolate. The experiment was repeated once. Percentage of infected plants per cultivar or line is presented. Numbers are means of two experiments. Means within columns with the same letter do not differ significantly with the least significant difference procedure at $P=0.05$.

z Percentage of tobacco seedlings with symptoms of $P$. nicotianae 14 days after inoculation.

We identified K-326 and K-346 as efficient differential cultivars for determining race 0 ; both cultivars exhibited high levels of mortality, especially 14 days after inoculation. NC-1071, NC-71, and L8 were sufficient to distinguish race 1 from race 0 . From the sample of the $21 \mathrm{P}$. nicotianae isolates, 8 were determined to be race 0 and 13 race 1 . In the cases of race 0 , no mortality was observed in either NC-1071 or L8; however, for race 1, plants from both NC-1071 and L8 developed symptoms of black shank. Thus, any combination of cultivars with partial resistance (such as K-326 or K-346) and complete resistance (such as NC-1071, NC-71, or L8) should be sufficient to distinguish race 0 from race 1 .

From the six differential cultivars examined, only one (Ky14xL8) produced unclear results; for five of the eight isolates determined as race 0, Ky14xL8 had levels of mortality ranging from 5 to $31 \%$. Ky14xL8 carries single-gene resistance conferred by the Phl gene from $N$. longiflora, and no mortality was expected when it was inoculated with race $0(12,23)$. A recent study (11) indicated that the $P h l$ gene is homologous to the $P h p$ gene from N. plumbaginifolia. It also has been suggested (11) that these two genes may be members of a complex resistance locus. Thus, the possibility cannot be ruled out that, when the $P h l$ gene is in a heterozygous form, as in the Ky14xL8 hybrid, resistance to race 0 is not expressed consistently.

Commonly, races of pathogens, especially soilborne pathogens, are determined in greenhouse assays. These assays usually require time and labor. Additionally, space limitation does not allow the inoculation of a large number of plants from each differential host; thus, results generated may not be always robust. Greenhouse experiments also are subject to variation in environmental conditions, especially air temperature, depending on the season they are conducted.

The laboratory technique we developed has a significant advantage over the greenhouse assay because it has lower labor and time requirements. The time between seeding and final evaluation, 14 days after inoculation, was 5 weeks for the laboratory technique and 7 to 8 weeks for the greenhouse technique. The laboratory technique required one-third of the space compared with the greenhouse technique for the same number of isolates. Furthermore, the greenhouse technique requires transplanting the tobacco seedlings into large pots and, thus, extra labor. With the laboratory technique, 10 to 16 seedlings per differential cultivars in each replicate and experiment were evaluated for black shank symptoms versus three plants with the greenhouse technique. The larger number of seedlings used in the laboratory increased the reliability of the results, espe- 
cially for isolates such as RM 27-6 2000-7 K346-49, which produced unclear results with respect to race determination.

Use of tobacco seedlings has been reported previously by Van Jaarsveld (23) and McIntyre (13) to screen for resistance to $P$. nicotianae. Van Jaarsveld (23) speculated that a seedling technique could be used to distinguish races of $P$. nicotianae. Although our seedling technique is not exactly the same as the one described by Van Jaarsveld, we confirm that race determination is feasible with tobacco seedlings. A major difference between Van Jaarsveld's (13) and the present study is the conclusions with regard to Ky14xL8 efficiency to distinguish race 0 from race 1. That could be attributed to either the difference in the disease assessment methods used by the two studies or the fact that, in the present study, the limitation of Ky14xL8 became evident during the validation process when a large number of $P$. nicotianae isolates were tested.

The laboratory technique also has some disadvantages: the seedlings require attention in handling, especially water and fertilizer. We found that the cells with the perlite should be watered carefully; otherwise, the seedlings were killed by excess water. Although seedlings are only a few weeks old, fertilizer also is important and should be applied regularly. Cultivars in the plates were not randomized in an effort to avoid seeding neighboring cells with the same cultivars. Occasionally, seedlings of neighboring cells are in contact and, thus, fungal mycelium from an infected seedling may infect healthy seedlings of the same cultivar in the next cell. Although this fact may not alter the final results, we considered that it would be better to use a nonrandomized pattern and avoid this possibility. Overall, by using the laboratory technique to evaluate a number of isolates of $P$. nicotianae, we reliably assigned them to races. We also propose that the technique could be useful with some modifications for other tobacco pathogens, especially soilborne pathogens such as Fusarium oxysporum.

\section{ACKNOWLEDGMENTS}

We thank S. A. Alayli and M. Perros for their assistance; the North Carolina Tobacco Research Commission for financial support; and R. Lewus, D. H. Shew, and T. Sutton for critical review of the manuscript before submission.

\section{LITERATURE CITED}

1. Apple, J. L. 1954. Variation in pathogenicity of Phytophthora parasitica var. nicotianae. Plant Dis. Rep. 38:774-776.

2. Apple, J. L. 1962. Physiological specialization within P. nicotianae var. parasitica. Phytopathology 52:351-354.

3. Apple, J. L. 1967. Occurrence of race 1 of Phytophthora nicotianae var. parasitica in North Carolina and its importance in breeding for disease resistance. Tob. Sci. 11:79-83.

4. Chaplin, J. F. 1962. Transfer of black shank resistance from Nicotiana plumbaginifolia to flue-cured $N$. tabacum. Tob. Sci. 6:184-189.

5. Collins, G. B., Legg, P. D., Litton, C. C., and Kasperbaur, M. J. 1971. Inheritance of resistance to black shank in Nicotiana tabacum L. Can. J. Genet. Cytol. 13:422-428.

6. Csinos, A. S. 1999. Stem and root resistance to tobacco black shank. Plant Dis. 83:777-780.

7. Csinos, A. S. 2005. Relationship of isolate origin to pathogenicity of race 0 and 1 of Phytophthora nicotianae var. parasitica on tobacco cultivars. Plant Dis. 89:332-337.

8. Fichtner, E. J., Hesterberg, D. L., and Shew, H. D. 2001. Nonphytotoxic aluminum-peat complexes suppress Phytophthora parasitica. Phytopathology 91:1090-1097

9. Gallup, C. A., and Shew, H. D. 2006. Race stability in Phytophthora nicotianae, the causal agent of black shank of tobacco. (Abstr.) Phytopathology 96:S37

10. Goins, R. B., and Apple, J. L. 1970. Inheritance and phenotypic expression of a dominant factor for black shank resistance for N. plumbaginifolia in a Nicotiana tabacum milieu. Tob. Sci.14:7-11.

11. Johnson, E. S., Wolff, M. F., Wernsman, E. A., Atchley, W. R., and Shew, H. D. 2002. Origin of the black shank resistance gene, $P h$, in tobacco cultivar Coker 371-Gold. Plant Dis.
86:1080-1084.

12. Lucas, G. B. 1975. Diseases of Tobacco. 3rd ed Biological Consulting Associates, Raleigh, NC.

13. McIntyre, J. L., and Taylor, G. S. 1976. Screening tobacco seedlings for resistance to Phytophthora parasitica var. nicotianae. Phytopathology 66:70-73.

14. McIntyre, J. L., and Taylor, G. S. 1978. Race 3 of Phytophthora nicotianae var. parasitica. Phytopathology 68:35-38.

15. Melton, T. A., Broadwell, A., and Wilson, J. 2005. Disease management. Pages 150-171 in Flue-Cured Tobacco Information. N. C. Coop. Ext. Serv. Bull. North Carolina State University, Raleigh.

16. Prinsloo, G. C., and Pauer, D. C. 1974. Die indentikikasie van rasse van Phytophthora nicotianae B de Haan var. parasitica wat in SuidAfrika voorkom. Phytophylaactica 6:217-220.

17. Smith, T. E., and Clayton, E. E. 1948. Resistance to bacterial wilt and black shank in fluecured tobacco. Phytopathology 38:227-229.

18. Sullivan, J. M., Melton, T. A., and Shew, H. D. 2005. Fitness of races 0 and 1 of Phytophthora parasitica var. nicotianae. Plant Dis. 89:12201228.

19. Sullivan, J. M., Melton, T. A., and Shew, H. D. 2005. Managing the race structure of Phy tophthora parasitica var. nicotianae with cultivar rotation. Plant Dis. 89:1285-1294.

20. Tisdale, W. B. 1931. Development of strains of cigar wrapper tobacco resistant to black shank (Phytophthora nicotianae Breda de Haan). Fla. Agric. Exp. Stn. Bull. 226:1-45.

21. Todd, F. A. 1981. Flue Cured TobaccoProducing a Healthy Crop. Tobacco Consultants, Wendell, NC.

22. Valleau, W. D., Stokes, G. W., and Johnson, E. M. 1960. Nine years' experience with the Nicotiana longiflora factor for resistance to Phytophthora parasitica var. nicotianae in the control of black shank. Tob. Sci. 4:92-94.

23. Van Jaarsveld, E., Wingfield, M. J., and Drenth, A. 2003. A rapid seedling based screening technique to assay tobacco for resistance to Phytophthora nicotianae. J. Phytopathol. 151:389-394.

24. Wills, W. H. 1971. A comparison of black shank resistance of tobacco measured in inoculated whole plants and excised leaf tissue. Tob. Sci. 15:47-50.

25. Wills, W. H., and Moore, L. D. 1971. Response of some cultivars and lines of tobacco to stem inoculation with Phytophthora nicotianae var. parasitica. Tob. Sci. 15:51-53. 